\title{
Strategi Pengembangan Agribisnis Kentang Berbasis Sumber Daya Manajemen di Kabupaten Banjarnegara
}

Agribusiness Development Strategy of Potato Based on

Management Resource Approach in Banjarnegara District

\author{
Siti Leny Puspasari ${ }^{* 1}$, Hartrisari Hadjomidjojo ${ }^{\# 2}$ dan Ma'mun Sarma ${ }^{\# 3}$ \\ ${ }^{1}$ Kementerian Riset dan Teknologi \\ Gedung 2 BPPT, JI. MH. Thamrin No. 8, Jakarta Pusat 10340 \\ ${ }^{2}$ Departemen Teknologi Industri Pertanian, Fakultas Teknologi Pertanian, Institut Pertanian Bogor \\ ${ }^{3}$ Departemen Manajemen, Fakultas Ekonomi Manajemen, Institut Pertanian Bogor \\ \#JI. Kamper, Kampus IPB Darmaga, Bogor 16680
}

\begin{abstract}
ABSTRAK
Hortikultura merupakan salah satu subsektor pertanian yang potensial untuk dikembangkan karena mempunyai nilai ekonomis dan nilai tambah cukup tinggi dibandingkan dengan komoditas lainnya. Komoditas hortikultura mempunyai peran strategik, terutama dalam upaya pemenuhan ketersediaan dan kecukupan pangan, peningkatan kesejahteraan petani, dan penyediaan lapangan kerja. Salah satu komoditas hortikultura umbi adalah kentang (Solanum tuberosum) merupakan komoditas sayuran yang memiliki peran penting dalam memenuhi kebutuhan pangan. Penelitian ini bertujuan untuk (1) mengidentifikasi faktor-faktor yang mempengaruhi pengembangan agribisnis komoditas kentang melalui pendekatan sumber daya manajemen di Kabupaten Banjarnegara, (2) merumuskan strategi pengembangan agribisnis komoditas kentang di Kabupaten Banjarnegara, dan (3) menentukan prioritas alternatif strategi untuk pengembangan agribisnis kentang di Kabupaten Banjarnegara. Metode analisis yang digunakan adalah analisis prospektif dan analytical hierarchy process (AHP). Berdasarkan analisis prospektif, diperoleh sepuluh faktor kunci yang mempengaruhi pengembangan agribisnis komoditas kentang di Kabupaten Banjarnegara. Berdasarkan AHP, faktor yang paling berpengaruh dalam penyusunan strategi pengembangan agribisnis komoditas kentang di Kabupaten Bajarnegara adalah produktivitas, sedangkan aktor yang memiliki peranan paling penting terhadap strategi pengembangan agribisnis komoditas kentang adalah pemerintah pusat/daerah. Tujuan yang ingin dicapai, paling utama adalah meningkatkan pendapatan petani, selanjutnya alternatif strategi yang penting untuk dilakukan dalam pengembangan agribisnis komoditas kentang di Kabupaten Banjarnegara adalah pemberdayaan petani/kelompok tani.
\end{abstract}

Kata kunci: hortikultura, strategi pengembangan, agribisnis, kentang

\section{ABSTRACT}

Horticulture is one of the agriculture sub-sector which is potential to be developed, because it has quite high economic value and added value compared to other commodities. One of horticultural commodity namely potato (Solanum Tuberosum) is a vegetable, which has an important role to fulfill food needs. Potato has potential and good prospect to support food diversification program in order to achieve sustainable food security. Potato commodity is one of the best commodities in Banjarnegara district. The study was aimed to (1) identify factors, that effect the agribusiness development of potato commodity through management resource approach in Banjarnegara district, (2) formulate agribusiness development strategy of potato commodity in Banjarnegara district and (3) determine the priority of alternative strategy for the agribusiness development of potato commodity in Banjarnegara district. Based on prospective analysis that there are 10 factors that effect the agribusiness development of potato commodity in Banjarnegara district. Agribusiness development strategy of potato commodity through management resource approach in Banjarnegara district is based on scenarios that the agribusiness will grow in the future. Based on AHP, the most influential factor in formulating agribusiness development strategy of potato commodity in Banjarnegara district is productivity.

Key words: strategy development, agribusiness, potato, prospective analysis, analytical hierarchy process

\footnotetext{
*) Korespondensi:

JI. MH. Thamrin No. 8, Jakarta Pusat; e-mail: leny_puspasari@yahoo.com
} 


\section{PENDAHULUAN}

Indonesia merupakan salah satu negara agraris yang memiliki sumber daya alam (SDA) yang beragam berpotensi untuk dikembangkan. Hortikultura merupakan salah satu subsektor pertanian potensial untuk dikembangkan, karena mempunyai nilai ekonomis dan nilai tambah cukup tinggi dibandingkan dengan komoditas lainnya. Komoditas hortikultura mempunyai peran strategik terutama dalam upaya pemenuhan ketersediaan dan kecukupan pangan, peningkatan kesejahteraan petani, serta penyediaan lapangan kerja. Sayuran merupakan salah satu komoditas hortikultura yang berkembang pesat di Indonesia baik dari segi jumlah produksi maupun mutunya. Sayuran dan buah-buahan merupakan komoditas yang esensial dalam pemenuhan kebutuhan dasar manusia akan kalori, vitamin, mineral, serat, dan anti oksidan alami (Direktorat Budidaya dan Pascapanen Sayuran dan Tanaman Obat, 2011). Secara umum produksi hortikultura, terutama sayuran dan buah-buahan menunjukkan perkembangan yang positif. Dari tahun 2007 hingga 2011, rataan produksi buah-buahan dan sayuran meningkat masing-masing $1,11 \%$ dan $3,58 \%$ (BPS dan Dirjen Hortikultura, 2011).

Salah satu komoditas hortikultura yaitu kentang (Solanum tuberosum) merupakan komoditas sayuran yang memiliki peran penting dalam memenuhi kebutuhan pangan. Kentang merupakan sumber kalori dan mineral yang penting bagi pemenuhan kebutuhan gizi masyarakat, serta mempunyai nilai ekonomi cukup baik. Pada masa mendatang, kentang diharapkan menjadi pangan alternatif sumber karbohidrat dan protein untuk membantu menguatkan ketahanan pangan. Dalam perkembangannya, mulai tahun 2007-2009 rataan luas panen, produksi dan produktivitas kentang cenderung meningkat masingmasing $6,95 \%, 8,27 \%$, dan $2,65 \%$. Namun sejak tahun 2010-2011 produktivitas kentang mengalami penurunan (BPS dan Dirjen Hortikultura, 2011). Hal ini disebabkan berkurangnya luas panen dan keterbatasan benih bermutu.

Provinsi Jawa Tengah merupakan sentra produksi kentang dengan luas panen terbesar. Salah satu wilayah di Jawa Tengah yang merupakan sentra penghasil kentang adalah Dataran Tingi Dieng, Kabupaten Banjarnegara. Penurunan produktivitas terjadi pula di Kabupaten Banjarnegara. Pada tahun 2006-2011 penurunan produktivitas rataan $3,67 \%$. Rendahnya mutu dan kuantitas benih kentang, fenomena anomali cuaca, kondisi lahan yang semakin rusak, serangan hama dan penyakit merupakan beberapa hal yang menyebabkan penurunan produktivitas.

Penelitian ini bertujuan (1) Mengidentifikasi faktor-faktor yang mempengaruhi pengembangan agribisnis kentang di Kabupaten Banjarnegara, (2) Merumuskan skenario strategi pengembangan agribisnis, dan (3) merumuskan prioritas alternatif strategi.

\section{METODOLOGI}

Solanum tuberosum, nama lain dari kentang. Kentang merupakan tanaman dikotil yang bersifat semusim, termasuk famili Solanaceae, dan memiliki umbi batang yang dapat dimakan. Tanaman kentang berbentuk semak atau herba. Batangnya berada di atas permukaan tanah, ada yang berwarna hijau, kemerah-merahan, atau ungu tua. Warna batang ini dipengaruhi oleh umur tanaman dan keadaan lingkungan. Pada kesuburan tanah yang baik atau lebih kering, biasanya warna batang tanaman yang lebih tua akan lebih menyolok. Bagian bawah batangnya bisa berkayu, sedangkan batang tanaman muda tidak berkayu sehingga tidak terlalu kuat dan mudah rubuh (Setiadi, 2009).

Tanaman kentang hanya tumbuh dan produktif pada jenis tanah ringan yang mengandung sedikit pasir dan kaya bahan organik. Tanaman kentang tumbuh baik di daerah dataran tinggi atau pegunungan dengan elevasi 800-1500 meter di atas permukaan laut (dpl). Tanaman kentang menghendaki suhu udara harus dingin, antara 15$22^{\circ} \mathrm{C}$ (optimumnya $18-20^{\circ} \mathrm{C}$ ) dengan kelembapan udara $80-90 \%$. Selain itu, Mulsa jerami perlu dihamparkan di bedengan jika kentang ditanam di dataran medium (Sukayana, et al, 2013). Curah hujan yang baik untuk pertumbuhan tanaman kentang adalah 2000-3000 mm/tahun. Tanaman kentang tumbuh pada tanah dengan $\mathrm{pH}$ tanah antara 5-5,5.

Data yang digunakan dalam penelitian ini meliputi data primer dan sekunder. Data primer diperoleh melalui wawancara, pengamatan langsung di lapangan, dan pengisian daftar pertanyaan (kuesioner) dengan petani dan stakeholders yang terkait dengan agribisnis kentang, maupun dari para pakar. Stakeholders/pakar sebanyak tujuh orang nara sumber yang berasal dari Badan Penerapan dan Pengkajian Teknologi (BPPT), Badan Tenaga Aton Nasional (BATAN), Institut Pertanian Bogor (IPB), Badan Perencanaan Pembangunan Daerah (BAPPEDA) Kabupaten Banjarnegara, Dinas Pertanian, Perikanan dan Peternakan Kabupaten Banjarnegara, Ketua Asosiasi Petani Kentang Dataran Tinggi Dieng, Ketua Asosiasi Penangkar Benih Kentang Kabupaten Banjarnegara

Data sekunder dikumpulkan dari laporanlaporan berkala atau tahunan, jurnal, buku-buku, studi kepustakaan dan publikasi penelitian sebelumnya. Data sekunder diperoleh dari Kementerian Pertanian, Direktorat Jenderal Hortikultura Kementerian Pertanian, Dinas Pertanian, Perikanan, dan Peternakan Kabupaten Banjarnegara, Badan Pembangunan Perencanaan Daerah Kabupaten Banjarnegara dan berbagai literatur yang mendukung penelitian ini.

Analisis data yang digunakan dalam penelitian ini adalah analisis prospektif untuk mengidentifikasi sumber daya manajemen yang mempengaruhi, menetapkan faktor dominan dan 
merancang skenario yang mungkin terjadi di masa dating. Untuk pengambilan keputusan prioritas alternatif strategi digunakan analytical hierarchy process (AHP).

Analisis prospektif merupakan salah satu teknik untuk menganalisis beragam strategi yang dapat terjadi di masa depan berdasarkan kondisi yang ada saat ini. Tujuan dari analisis prospektif adalah mempersiapkan strategi, apakah perubahan diperlukan di masa depan. Dari analisis prospektif didapatkan informasi mengenai faktor kunci dan tujuan strategi apa saja yang berperan dalam pengembangan agribisnis komoditas kentang di Kabupaten Banjarnegara sesuai dengan kebutuhan para pemangku kepentingan (stakeholders) yang terlibat di dalam pemanfaatan masa depan. Selanjutnya faktor kunci dan tujuan strategi (kebutuhan) tersebut digunakan untuk mendefinisikan dan mendeskripsikan evolusi kemungkinan masa depan bagi agribisnis kentang di Kabupaten Banjarnegara.

Analisis prospektif digunakan untuk (1) mempersiapkan tindakan strategik, (2) melihat apakah perubahan dibutuhkan di masa depan. Tiga langkah yang perlu dilakukan dalam prospektif partisipatif, yaitu (1) mengidentifikasi faktor penentu di masa depan, (2) menentukan tujuan strategis dan kepentingan pelaku utama, (3) mendefinisikan dan mendeskripsikan evolusi kemungkinan masa depan (Bourgeois dan Jesus, 2004).

Menurut Hardjomidjojo (2002), analisis prospektif digunakan untuk melihat kemungkinankemungkinan yang terjadi di masa depan. Analisis prospektif tidak sama dengan peramalan karena dari analisis prospektif dapat diprediksi alternatifalternatif yang akan terjadi di masa mendatang, baik yang bersifat positif (diinginkan) maupun yang negatif (tidak diinginkan). Kegunaan analisis prospektif adalah untuk mempersiapkan tindakan strategik yang perlu dilakukan dan melihat apakah perubahan dibutuhkan di masa depan. Analisis prospektif merupakan pengembangan dari metode Delphi yang menggunakan pendapat kelompok pakar yang memahami persoalan dengan benar untuk pengambilan keputusan dan strategi kebijakan, dengan tahapan berikut:

1. Menentukan tujuan sistem yang dikaji. Tujuan sistem yang dikaji perlu spesifik dan dimengerti oleh semua pakar yang akan diminta pendapatnya. Hal ini dilakukan agar pakar mengerti ruang lingkup kajian dan penyamaan pandangan tentang sistem yang dikaji. Tujuan sistem yang dikaji adalah pengembangan agribisnis komoditas kentang di Kabupaten Banjarnegara.

2. Identifikasi faktor-faktor yang berpengaruh dalam pencapaian tujuan tersebut, biasanya merupakan kebutuhan stakeholders dari sistem yang dikaji. Berdasarkan tujuan yang ingin dicapai, pakar diminta mengidentifikasi faktor-faktor yang berpengaruh dalam pencapaian tujuan tersebut. Untuk kajian ini perlu diidentifikasi faktor-faktor yang berpengaruh pada pengembangan agribisnis komoditas kentang.

3. Penilaian pengaruh langsung antar faktor. Semua faktor yang teridentifikasi dinilai pengaruh langsung antar faktor. Pedoman penilaian dapat dilihat pada Tabel 1 .

Tabel 1. Pedoman penilaian analisis prospektif

\begin{tabular}{cc}
\hline Skor & Pengaruh \\
\hline 0 & Tidak ada pengaruh \\
1 & Berpengaruh kecil \\
2 & Berpengaruh sedang \\
3 & Berpengaruh sangat kuat \\
\hline
\end{tabular}

Sumber: Bourgeois dan Jesus, 2004.

Hasil matriks gabungan dari pendapat pakar diolah dengan perangkat lunak analisis prospektif dengan teknik statistik untuk menghitung pengaruh langsung global, ketergantungan global, kekuatan global dan kekuatan global tertimbang. Hasil perhitungan divisualisasikan dalam diagram pengaruh dan ketergantungan antar faktor Gambar 1.

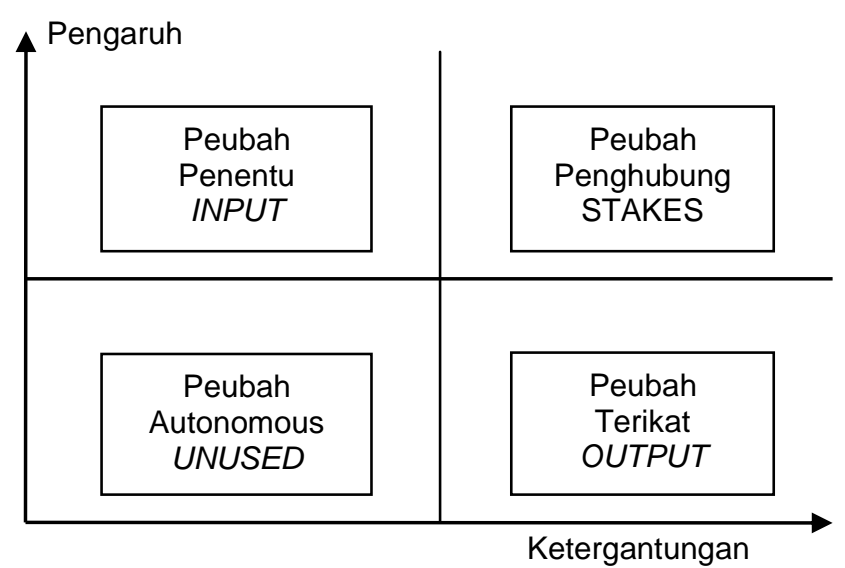

Gambar 1. Pengaruh dan ketergantungan sistem (Bourgeois dan Jesus, 2004)

4. Penyusunan keadaan yang mungkin terjadi (state) pada faktor. Berdasarkan faktor dominan yang diperoleh pada tahap 3 , disusun keadaan yang mungkin terjadi di masa depan. Setiap faktor boleh memiliki lebih dari satu keadaan, dengan ketentuan keadaan harus memiliki peluang sangat besar untuk terjadi (bukan khayalan) dalam suatu waktu di masa yang akan datang. Keadaan bukan merupakan tingkatan atau ukuran suatu faktor (seperti besar, sedang, kecil, atau baik/buruk), tetapi merupakan deskripsi tentang situasi dari sebuah faktor.

5. Membangun dan memilih skenario. Skenario disusun berdasarkan kombinasi dari hubungan beberapa keadaan faktor secara timbal balik (mutual compatible) dari keadaan paling optimis sampai paling pesimis.

6. Analisis skenario dan penyusunan strategi. Berdasarkan skenario yang disusun pada tahap sebelumnya didiskusikan strategi yang 
perlu dilakukan untuk pencapaian skenario yang diinginkan, ataupun menghindari skenario yang berdampak negatif pada sistem.

Dari hasil analisis prospektif, kemudian dirumuskan alternatif strategi dengan menggunakan metode AHP. Dalam Ma'arif dan Tanjung (2003), AHP ditujukan untuk membuat model permasalahan yang tidak terstruktur dan biasanya diterapkan untuk memecahkan masalah-masalah terukur, maupun masalah-masalah yang memerlukan pendapat (judgement), atau merupakan analisis yang digunakan bagi pengambil keputusan untuk memahami kondisi sistem dan membantu melakukan prediksi dalam mengambil keputusan. Dalam menyelesaikan persoalan dengan AHP, terdapat beberapa prinsip yang harus dipahami, diantaranya decomposition, comparative judgement, synthesis of priority, dan logical consistency.

Prinsip kerja AHP adalah penyederhanaan suatu persoalan kompleks yang tidak terstruktur, strategik dan dinamik menjadi bagian-bagiannya, serta menata dalam suatu hirarki. Kemudian tingkat kepentingan setiap peubah diberi nilai numerik secara subyektif tentang arti penting peubah tersebut secara relatif dibandingkan dengan peubah yang lain.

Dari berbagai pertimbangan tersebut dilakukan sintesa untuk menetapkan peubah yang memiliki prioritas tinggi dan berperan untuk mempengaruhi hasil pada sistem tersebut. AHP memiliki banyak keunggulan dalam menjelaskan proses pengambilan keputusan, karena dapat digambarkan secara grafis, sehingga mudah dipahami oleh semua pihak yang terlibat dalam pengambilan keputusan (Marimin, 2008).

\section{HASIL DAN PEMBAHASAN}

\section{Identifikasi Sumber Daya Manajemen}

Sumber daya manajemen (SDM) dalam strategi pengembangan agribisnis komoditas kentang di Kabupaten Banjarnegara dikelompokkan ke dalam 7M+1TI, yaitu Man, Materials, Money, Methods, Market, Machines, Management, Time, dan Information. Berdasarkan hasil diskusi dengan pakar/stakeholders didapatkan 21 faktor yang mempengaruhi pengembangan agribisnis komoditas kentang di Kabupaten Banjarnegara.

Faktor-faktor tersebut meliputi kepentingan dari setiap sumber daya manajemen $(7 \mathrm{M}+1 \mathrm{TI})$, yaitu man (pendidikan dan pengetahuan petani, penyuluhan dan pelatihan); materials (sarana produksi pertanian, potensi lahan); money (dukungan lembaga keuangan, dan kemampuan permodalan); methods (teknik budi daya, produktivitas, penanganan pascapanen); market (permintaan pasar, dan sistem tata niaga); machines (mesin/alat pertanian, sarana transportasi dan penggunaan teknologi ramah lingkungan); management (keterlibatan pemerintah pusat dan daerah, pola kemitraan); time (penggunaan sarana produksi, pengaturan waktu tanam/ panen); information (informasi pasar, kebijakan pemerintah dan informasi hasil litbang mutakhir. Setela teridentifikasi faktor-faktor yang mempengaruhi pengembangan agribisnis komoditas kentang, kemudian pakar/stakeholdres diminta menetapkan definisi dari masing-masing faktor (Tabel 2).

\section{Analisis Pengaruh Langsung Antar Faktor}

Setelah dilakukan identifikasi faktor-faktor yang mempengaruhi dalam pengembangan agribisnis dan pendefinisian faktor, maka selanjutnya penilaian pengaruh antar faktor. Penilaian pengaruh langsung antar faktor oleh pakar diolah dengan menggunakan perangkat lunak analisis prospektif yang divisualisasikan dalam diagram pengaruh dan ketergantungan faktor (Gambar 2).

Berdasarkan pendapat gabungan pakar diperoleh faktor-faktor yang terdapat pada Kuadran I dan II yang merupakan faktor kunci sangat berpengaruh terhadap pengembangan agribisnis. Dapat disimpulkan terdapat 10 faktor kunci yang mempengaruhi pengembangan agribisnis kentang di Kabupaten Banjarnegara, yaitu (1) kebijakan pemerintah; (2) pendidikan dan pengetahuan petani; (3) potensi lahan; (4) pelatihan dan penyuluhan; (5) informasi hasil litbang mutakhir; (6) pengaturan waktu tanam/panen; (7) sarana produksi pertanian; (8) pengaturan penggunaan sarana produksi; (9) keterlibatan pemerintah pusat dan daerah; dan (10) produktivitas. Berdasarkan faktor kunci tersebut, selanjutnya diformulasikan skenario pengembangan agribisnis kentang di Kabupaten Banjarnegara.

\section{Formulasi Strategi Pengembangan Agribisnis Komoditas Kentang}

Skenario pengembangan agribisnis disusun berdasarkan faktor-faktor kunci yang berpengaruh terhadap pengembangan agribisnis kentang di Kabupaten Banjarnegara. Berdasarkan faktorfaktor tersebut selanjutnya dideskripsikan tentang berbagai keadaan (state) yang mungkin terjadi di masa mendatang. Dari kesepuluh faktor kunci yang berpengaruh terhadap pengembangan agribisnis, selanjutnya dipilih keadaan yang mungkin terjadi di masa mendatang.

Pemetaan keadaan faktor penentu pengembangan agribisnis kentang di Kabupaten Banjarnegara yang mungkin terjadi di masa mendatang dapat dilihat pada Tabel 3 . Berdasarkan keadaan yang dibuat, maka disusun skenario tentang kemungkinan-kemungkinan yang akan terjadi untuk pengembangan agribisnis di masa mendatang. Skenario yang disusun diharapkan sesuai dengan konsep agribisnis yang memerlukan integrasi yang baik antar seluruh subsistem yang membentuk sistem agribisnis (Romaully, 2012). Skenario disusun dalam rangka menghasilkan rekomendasi operasional untuk pengembangan agribisnis di masa depan. 
Skenario pengembangan agribisnis kentang di Kabupaten Banjarnegara dapat dilihat pada Tabel 4. Skenario 1 adalah skenario optimis, maka perlu didorong untuk terjadi. Skenario 2 adalah skenario moderat merupakan cerminan dari kebutuhan para pemangku kepentingan dengan mempertimbangkan kemampuan memperbaiki berbagai faktor penentu. Skenario 3 adalah skenario pesimis, maka pihak pengambil kebijakan hendaknya berusaha menghindari terjadinya kemungkinan hal tersebut terjadi. Berdasarkan kemungkinan terjadinya di masa datang, skenario optimis (skenario 1) merupakan skenario yang paling mungkin terjadi dibandingkan dengan skenario-skenario lainnya.

Tabel 2. Definisi faktor-faktor yang mempengaruhi pengembangan agribisnis komoditas kentang di Kabupaten Banjarnegara

\begin{tabular}{cl}
\hline No & \multicolumn{1}{c}{ Faktor } \\
\hline 1 & Pendidikan dan pengetahuan \\
2 & Pelatihan dan penyuluhan \\
& \\
3 & Sarana produksi pertanian \\
4 & Potensi lahan
\end{tabular}

5 Dukungan lembaga keuangan

6 Kemampuan permodalan

7 Teknik budi daya

8 Produktivitas

9 Penanganan pascapanen

10 Permintaan pasar

11 Sistem tata niaga

12 Mesin/alat pertanian

13 Sarana transportasi

14 Penggunaan teknologi ramah lingkungan

15 Keterlibatan pemerintah pusat dan daerah

16 Pola kemitraan

17 Pengaturan waktu tanam/panen

18 Pengaturan penggunaan sarana produksi (kapan diberikan, berapa kali pemberian)

19 Informasi pasar

20 Kebijakan pemerintah

21 Informasi hasil penelitian dan pengembangan (litbang) mutakhir

Tingkat pendidikan dan pengetahuan yang dimiliki petani.

Proses pendidikan jangka pendek yang menggunakan cara dan prosedur sistematis dan terorganisir untuk memperoleh pengetahuan dan meningkatkan keterampilan yang sifatnya praktis untuk tujuan tertentu.

Bahan atau alat untuk mendukung kegiatan produksi pertanian.

Tanah merupakan faktor produksi penting, karena merupakan tumbuhnya tanaman, dan usahatani keseluruhannya.

Lembaga pembiayaan agribisnis memegang peranan sangat penting dalam mengembangkan usaha agribisnis, terutama dalam penyediaan modal investasi dan modal kerja, mulai dari sektor hulu sampai hilir.

Kemampuan mendapatkan dana guna mengembangkan usahanya.

Proses menghasilkan bahan pangan dan produk-produk agroindustri dengan memanfaatkan sumber daya tumbuhan.

Produktivitas merupakan perbandingan antara hasil yang dicapai (output) dengan keseluruhan sumber daya yang digunakan (input).

Penanganan pasca panen adalah tindakan yang disiapkan atau dilakukan pada tahapan pasca panen, sehingga hasil pertanian siap dan aman digunakan oleh konsumen dan/atau diolah lebih lanjut oleh industri

Permintaan pasar merupakan keinginan konsumen untuk membeli suatu barang pada berbagai tingkat harga selama periode waktu tertentu.

Sejumlah kegiatan bisnis yang ditujukan untuk memberi kepuasan dari barang, atau jasa yang dipertukarkan kepada konsumen, atau pemakai dalam bidang agribisnis.

Berbagai alat yang digunakan dalam usahatani.

Alat atau fasilitas dalam kegiatan mengangkut atau membawa sarana produksi maupun hasil pertanian.

Teknologi agribisnis mencakup teknologi dalam berbagai aktivitas agribisnis, mulai dari aktivitas pengadaan dan penyaluran sarana produksi pertanian, aktivitas produksi, pengolahan hingga pemasaran.

Pemerintah memegang peranan sangat penting dalam menciptakan lingkungan usaha agribisnis kondusif dan mampu mendukung pengembangan agribisnis yang tangguh.

Kemitraan sangat diperlukan dalam program pembangunan usahatani, terutama adanya interaksi antara industri baik skala kecil maupun besar yang mempunyai modal, wadah untuk menampung hasil panen dan memiliki inovasi terbaru

Hubungan waktu dan produksi, misalnya pengaturan dan teknologi kapan panen, agar petani memperoleh keuntungan tinggi.

Hubungan antara waktu dengan faktor produksi maupun produksinya, misalnya hubungan waktu dengan penggunaan pupuk, kapan diberikan dan berapa kali pemberian akan berpengaruh pada jumlah produk yang dihasilkan.

Informasi mengenai harga, sumber-sumber penawaran, mutu, dan sumber produk.

Ketersediaan peraturan/kebijakan pemerintah yang akomodatif.

Informasi mengenai inovasi teknologi hasil litbang lembaga riset. 
Tabel 3. Pemetaan keadaan faktor penentu pengembangan agribisnis kentang di Kabupaten Banjarnegara

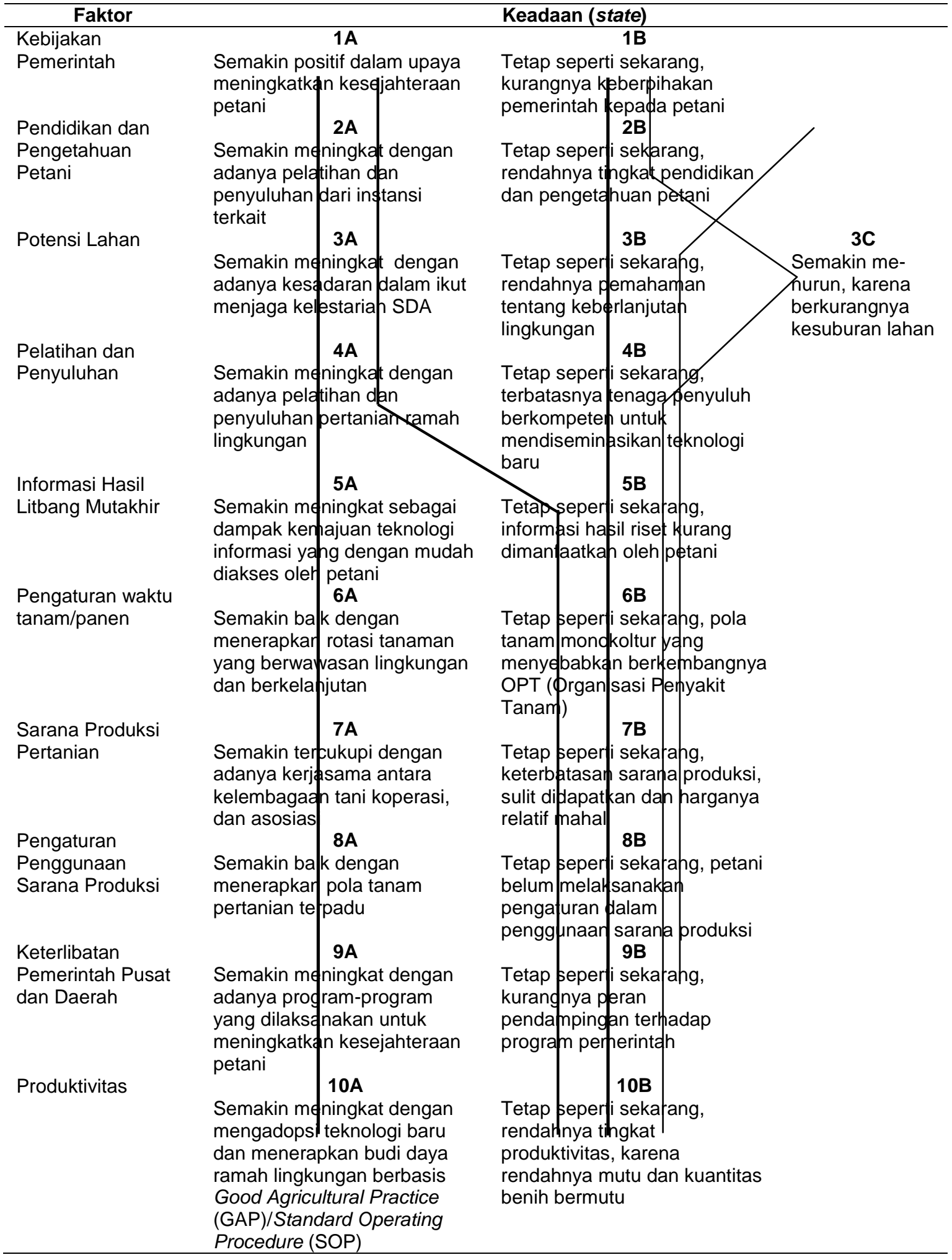

Tabel 4. Skenario Pengembangan Agribisnis Kentang di Kabupaten Banjarnegara

\begin{tabular}{|c|c|c|}
\hline \multicolumn{2}{|c|}{ Kondisi sekarang (Baseline) } & 1B-2B-3B-4B-5B-6B-7B-8B-9B-10B \\
\hline No & Skenario & Keadaan \\
\hline 1 & Optimis & 1A-2A-3A-4A-5A-6A-7A-8A-9A-10A \\
\hline 2 & Moderat & $1 A-2 A-3 A-4 A-5 B-6 B-7 B-8 B-9 B-10 B$ \\
\hline 3 & Pesimis & 1B-2B-3C-4B-5B-6B-7B-8B-9B-10B \\
\hline
\end{tabular}




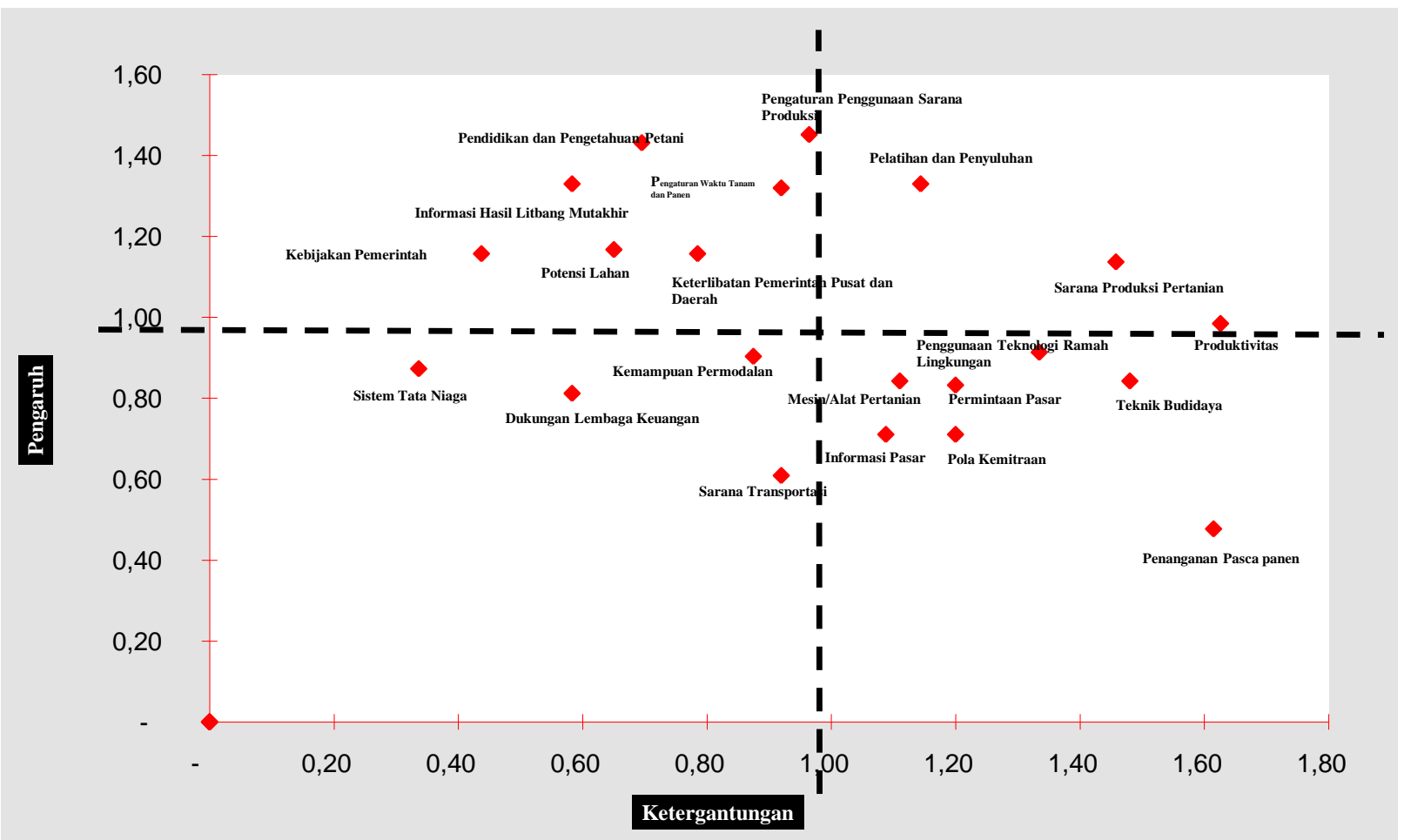

Gambar 2. Tingkat kepentingan faktor-faktor yang berpengaruh pada sistem yang dikaji

\section{Analisis Pemilihan Alternatif Strategi Pengembangan Agribisnis Komoditas Kentang di Kabupaten Banjarnegara}

Berdasarkan pengolahan data pada tingkat kedua dengan menggunakan metode AHP, diperoleh hasil bahwa faktor yang berpengaruh dalam penyusunan strategi pengembangan agribisnis komoditas kentang di Kabupaten Banjarnegara adalah produktivitas dengan bobot 0,144 (Tabel 5).

Tabel 5. Bobot dan prioritas faktor-faktor dalam strategi pengembangan agribisnis komoditas kentang

\begin{tabular}{lcc}
\hline \multicolumn{1}{c}{ Faktor } & Bobot & Prioritas \\
\hline Produktivitas & $\mathbf{0 , 1 4 4}$ & $\mathbf{1}$ \\
Kebijakan Pemerintah & 0,135 & 2 \\
Pengaturan Waktu Tanam/Panen & 0,132 & 3 \\
$\begin{array}{l}\text { Keterlibatan Pemerintah Pusat } \\
\text { dan Daerah }\end{array}$ & 0,128 & 4 \\
$\begin{array}{l}\text { Pengaturan Penggunaan Sarana } \\
\text { Produksi Pertanian }\end{array}$ & 0,095 & 5 \\
$\begin{array}{l}\text { Pelatihan dan Penyuluhan } \\
\text { Sarana Produksi Pertanian }\end{array}$ & 0,084 & 6 \\
$\begin{array}{l}\text { Pendidikan dan Pengetahuan } \\
\text { Petani }\end{array}$ & 0,083 & 7 \\
Potensi Lahan & 0,078 & 8 \\
Informasi Hasil Litbang Mutakhir & 0,047 & 10 \\
\hline
\end{tabular}

Pemerintah pusat dan daerah merupakan aktor yang memiliki peranan paling penting terhadap strategi pengembangan agribisnis komoditas kentang dengan bobot 0,365 (Tabel 6).

Tabel 6. Bobot dan prioritas aktor dalam strategi pengembangan agribisnis komoditas kentang

\begin{tabular}{lcc}
\hline \multicolumn{1}{c}{ Aktor } & Bobot & Prioritas \\
\hline Pemerintah Pusat dan Daerah & $\mathbf{0 , 3 6 5}$ & $\mathbf{1}$ \\
Lembaga Penelitian & 0,223 & 2 \\
Petani & 0,177 & 3 \\
Lembaga Keuangan & 0,113 & 4 \\
Pengusaha & 0,111 & 5 \\
\hline
\end{tabular}

Tabel 7 menunjukkan bahwa meningkatkan pendapatan petani dengan bobot 0,347 menjadi tujuan utama dalam strategi pengembangan agribisnis komoditas kentang.

Tabel 7. Bobot dan prioritas tujuan yang ingin dicapai dalam strategi pengembangan agribisnis komoditas kentang

\begin{tabular}{|c|c|c|}
\hline Tujuan & Bobot & Prioritas \\
\hline $\begin{array}{l}\text { Meningkatkan Pendapatan } \\
\text { Petani }\end{array}$ & 0,347 & 1 \\
\hline Peningkatan Nilai Tambah & 0,290 & 2 \\
\hline Meningkatkan Produktivitas & 0,229 & 3 \\
\hline Membuka Lapangan Usaha & 0,119 & 4 \\
\hline
\end{tabular}

Alternatif strategi paling penting untuk dilakukan adalah pemberdayaan petani/kelom-pok tani dengan bobot 0,219 (Tabel 8). 
Tabel 8. Bobot dan prioritas alternatif strategi pengembangan agribisnis komoditas kentang

\begin{tabular}{|c|c|c|}
\hline Alternatif Strategi & Bobot & Prioritas \\
\hline $\begin{array}{l}\text { Pemberdayaan } \\
\text { Petani/Kelompok Tani }\end{array}$ & 0,219 & 1 \\
\hline Meningkatkan Teknik Budidaya & 0,217 & 2 \\
\hline $\begin{array}{l}\text { Meningkatkan Dukungan } \\
\text { Sarana dan Prasarana }\end{array}$ & 0,214 & 3 \\
\hline $\begin{array}{l}\text { Meningkatkan Jaringan } \\
\text { Informasi dan Kemitraan }\end{array}$ & 0,182 & 4 \\
\hline $\begin{array}{l}\text { Meningkatkan Penelitian dan } \\
\text { Pengembangan }\end{array}$ & 0,168 & 5 \\
\hline
\end{tabular}

\section{Rekomendasi Operasional}

Pada Gambar 3 dapat dilihat bahwa tujuan strategi adalah mendorong agar skenario optimis terjadi, yaitu menjadi agribisnis kentang yang ideal di masa depan. Produktivitas sebagai faktor yang mempunyai pengaruh sangat besar dalam pengembangan agribisnis kentang di masa mendatang untuk mewujudkan terjadinya skenario optimis, yaitu menjadi agribisnis kentang ideal di Kabupaten Banjarnegara.

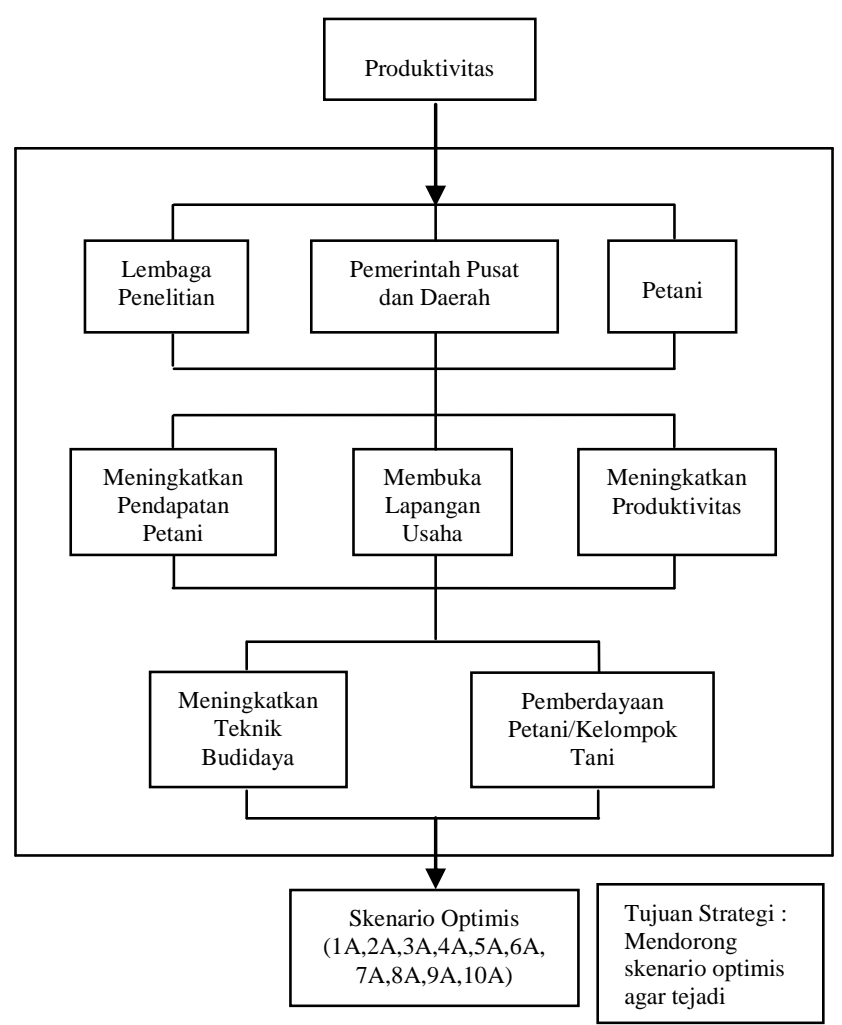

Gambar 3. Formulasi strategi pengembangan agribisnis komoditas kentang melalui pendekatan Sumber Daya Manajemen di Kabupaten Banjarnegara (Sintesis hasil analisis prospektif dan AHP)
Roadmap Strategi Pengembangan Agribisnis Komoditas Kentang di Kabupaten Banjarnegara

Roadmap pengembangan agribisnis komoditas kentang disusun berdasarkan skenario-skenario yang dapat terjadi. Kondisi optimis diharapkan terjadi dengan mendorong kondisi moderat. Tahapan yang dilakukan untuk mendorong terjadinya kondisi optimis dimulai dari kondisi saat ini (baseline). Jika kondisi saat ini tidak dapat ditingkatkan atau dipertahankan, maka kondisi pesimis dapat terjadi dan kondisi pesimis dapat ditingkatkan kembali menjadi keadaan sekarang. Selain dapat ditingkatkan menjadi kondisi saat ini, kondisi pesimis juga bisa meningkat menjadi kondisi moderat.

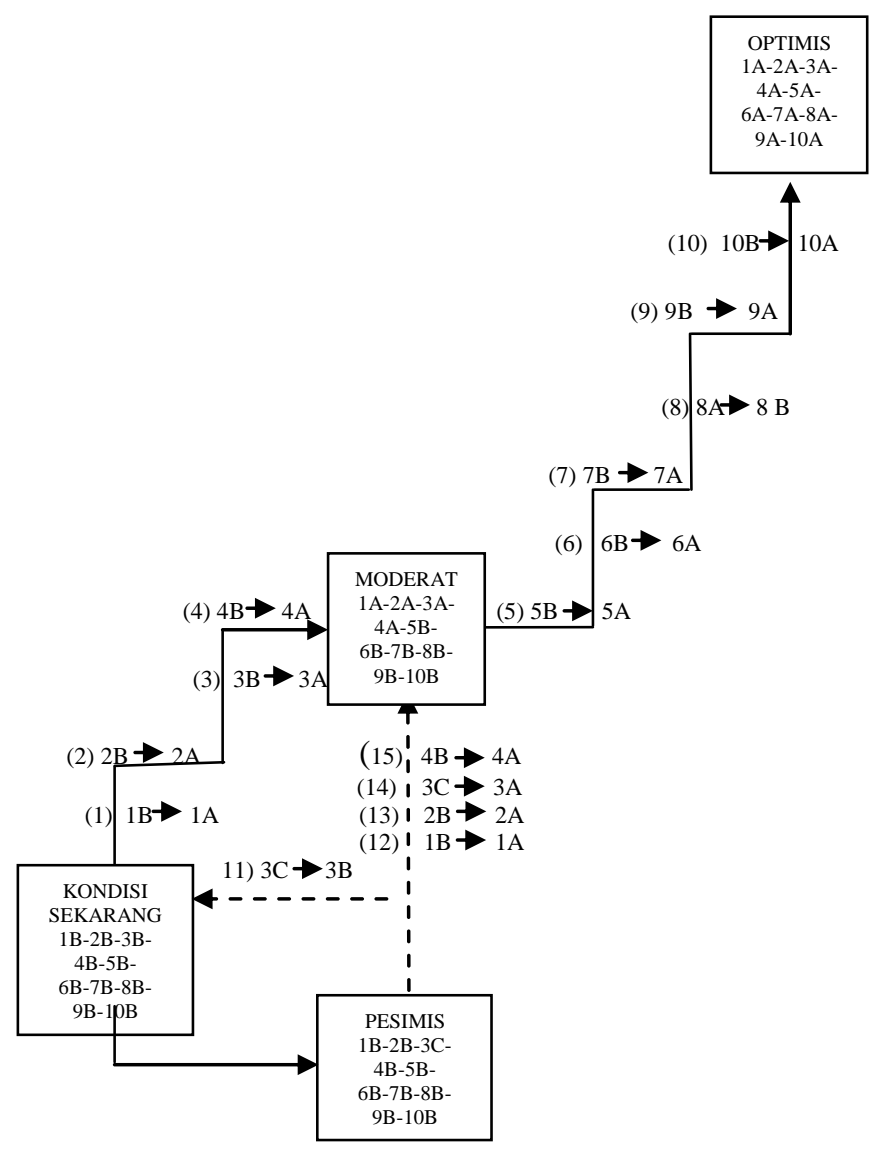

Gambar 4. Roadmap pengembangan agribisnis komoditas kentang di Kabupaten Banjarnegara

\section{KESIMPULAN}

Faktor-faktor kunci yang mempengaruhi pengembangan agribisnis komoditas kentang melalui pendekatan SDM di Kabupaten Banjarnegara, adalah (1) kebijakan pemerintah; (2) pendidikan dan pengetahuan petani; (3) potensi lahan; (4) pelatihan dan penyuluhan; (5) informasi hasil litbang mutakhir; (6) pengaturan waktu tanam/panen; (7) sarana produksi pertanian; (8) pengaturan penggunaan sarana produksi; (9) 
keterlibatan pemerintah pusat dan daerah; dan (10) produktivitas.

Skenario disusun berdasarkan faktor kunci yang sangat menentukan pengembangan agribisnis di Kabupaten Banjarnegara. Skenario terpilih untuk pengembangan agribisnis adalah skenario optimis menjadi kentang ideal di masa depan.

Faktor yang paling berpengaruh dalam penyusunan strategi pengembangan agribisnis komoditas kentang di Kabupaten Bajarnegara adalah produktivitas; aktor yang memiliki peranan paling penting terhadap strategi pengembangan agribisnis komoditas kentang adalah pemerintah pusat dan daerah, tujuan utama yang ingin dicapai adalah meningkatnya pendapatan petani, dan alternatif strategi yang penting untuk dilakukan dalam pengembangan agribisnis komoditas kentang di Kabupaten Banjarnegara adalah pemberdayaan petani/ kelompok tani.

\section{DAFTAR PUSTAKA}

Bourgeois R, Jesus F. 2004. Participatory Prospective Analysis: Exploring and Anticipating Challenges with Stakeholders. UNESCAP-CAPSA. Through Secondary Crops' Development in Asia and the Pacific. CAPSA Monograph No. 46.

[Dirjen] Direktorat Jenderal Hortikultura. 2011. Pedoman Pengembangan Hortikultura Tahun 2012: 2. [terhubung berkala]. http://hortikultura. deptan.go.id. [24 Mei 2012].
Direktorat Budidaya dan Pascapanen Sayuran dan Tanaman Obat. 2011. Pedoman Teknis Pengembangan Sayuran dan Tanaman Obat Tahun 2012:1. [terhubung berkala]. http://hortikultura. deptan.go.id. [24 Mei 2012].

Hardjomidjojo, H. 2002. Metode Analisis Prospektif. Bogor: Departemen Teknologi Industri Pertanian, Fakultas Teknologi Pertanian, Institut Pertanian Bogor, Bogor.

Ma'arif MS, Tanjung H. 2003. Teknik-Teknik Kuantitatif untuk Manajemen. PT Gamedia Widiasarana Indonesia, Jakarta.

Marimin. 2008. Teknik dan Aplikasi Pengambilan Keputusan Kriteria Majemuk. PT Gamedia Widiasarana Indonesia, Jakarta.

Romaully, M. 2012. Pengembangan Sistem Agribisnis Komoditas Kacang Tanah Sebagai Upaya Peningkatan Kontribusi Pertanian Terhadap PAD Kabupaten Hulu Sungai Utara. Median Sains, 4(1): 6-14.

Setiadi. 2009. Budi Daya Kentang. Penebar Swadaya, Jakarta.

Sukayana, I.M., D.P. Darmawan, dan N.P.U. Wijayanti. 2013. Rantai Nilai Komoditas Kentang Granola di Desa Candikuning Kecamatan Baturiti Kabupaten Tabanan. EJurnal Agribisnis dan Agrowisata, 2(3): 99108. 